\title{
PENGARUH PEMBERIAN GIBERELIN DAN PUPUK KALIUM TERHADAP PERTUMBUHAN DAN PRODUKSI TANAMAN BAWANG MERAH (Allium ascalonicum L.)
}

\section{The Effect of Gibberellin and Potassium Fertilizer on Growth and Production of Shallot (Allium ascalonicum L.)}

\author{
Nora Katrin, Nurbaiti, Murniati \\ Jurusan Agroteknologi, Program Studi Agroteknologi, Fakultas Pertanian, Universitas Riau \\ Email: norakatrin1@gmail.com/082167659783 \\ [Diterima: Februari 2021; Disetujui: April 2021]
}

\begin{abstract}
This research aims to find out the interaction effect of gibberellin and potassium fertilizer doses, to examine the effect potassium fertilizer doses on various gibberellin concentrations, gibberellin concentrations on various potassium fertilizer doses, and to find the main effect of gibberellin and potassium fertilizer which is better for growth and the production of shallot plant. The research was conducted at the UPT of the Faculty of Agriculture, Riau University, Pekanbaru, starting from December 2018 to February 2019. The method was experimentally arranged using the completely randomized block design. The main plot was the gibberellin concentrations $(0,100,200$ and 300) ppm. The sub plot was the dose of potassium fertilizer (100 and 200) $\mathrm{kg}$ of $\mathrm{KCl} \mathrm{ha}{ }^{-1}$. The parameter observed were plant height, total of leaves, diameter of bulbs, total bulbs per clump, fresh weight of bulbs per clump/plot, and dry weight of bulbs. The data were analyzed statistically with anova and Duncan test continued level of 5\%. There was interaction effect of gibberellin and potassium fertilizer increased the fresh weight of bulbs. The treatment $100 \mathrm{~kg}$ of KCl ha ${ }^{-1}$ and $200 \mathrm{ppm}$ of gibberellin increased the fresh weight and dry weight of bulbs. The treatment $200 \mathrm{~kg}_{\text {of KCl ha- }}{ }^{-1}$ and $200 \mathrm{ppm}$ of gibberellin was better to increase the total of leaves and diameter of bulbs. The treatment of gibberellin $200 \mathrm{ppm}$ was better to increase the fresh weight and dry weight of bulbs. The treatment of 200 of KCl ha $^{-1}$ increased the plant height and total of leaves.
\end{abstract}

Keywords : Gibberellin, Potassium, Shallot, Growth and Production

\begin{abstract}
ABSTRAK
Penelitian ini bertujuan untuk mengetahui pengaruh interaksi pemberian giberelin dan dosis kalium, pengaruh dosis kalium pada berbagai konsentrasi giberelin, konsentrasi giberelin pada berbagai dosis kalium, pengaruh utama pupuk kalium dan giberelin yang lebih baik terhadap pertumbuhan dan produksi tanaman bawang merah. Penelitian ini dilaksanakan di Kebun Percobaan, Fakultas Pertanian Universitas Riau, Pekanbaru, pada bulan Desember 2018 hingga Februari 2019 secara eksperimen disusun dalam rancangan petak terbagi dengan menggunakan rancangan acak lengkap. Petak utama adalah giberelin konsentrasi (0, 100, 200 dan 300) ppm. Anak petak pupuk kalium dosis (100 dan 200) $\mathrm{kg} \mathrm{KCl} \mathrm{ha}^{-1}$. Data yang diperoleh dianalisis secara statistik menggunakan sidik ragam dan dilanjutkan dengan uji jarak berganda Duncan pada taraf 5\%. Parameter yang diamati adalah tinggi tanaman, jumlah daun per rumpun, jumlah umbi per rumpun, diameter umbi, berat segar umbi per rumpun, berat segar umbi per plot, dan berat umbi layak simpan. Hasil penelitian memperlihatkan bahwa terdapat interaksi pemberian giberelin dengan pupuk $\mathrm{KCl}$ pada parameter berat segar umbi. Pemberian pupuk KCl $100 \mathrm{~kg} \cdot \mathrm{ha}^{-1}$ dan giberelin $200 \mathrm{ppm}$ menunjukkan pertumbuhan yang lebih baik pada parameter jumlah umbi, berat segar umbi dan berat umbi layak simpan. Pemberian pupuk KCl $200 \mathrm{~kg} \cdot \mathrm{ha}^{-1}$ dan giberelin $100 \mathrm{ppm}$ menunjukkan pertumbuhan yang lebih baik pada parameter jumlah daun dan diameter umbi. Pemberian giberelin $200 \mathrm{ppm}$ lebih baik dalam meningkatkan berat segar umbi dan berat umbi layak simpan. Pemberian kalium pada $200 \mathrm{~kg}$ $\mathrm{KCl} \mathrm{ha}{ }^{-1}$ lebih baik meningkatkan tinggi dan jumlah daun tanaman bawang merah.
\end{abstract}

Kata kunci : Giberelin, Kalium, Bawang Merah, Pertumbuhan dan Produksi 


\section{PENDAHULUAN}

Bawang merah (Allium ascalonicum L.) merupakan komoditas hortikultura yang memiliki banyak manfaat sehingga bernilai ekonomis tinggi. Sayuran rempah ini banyak dibutuhkan terutama sebagai pelengkap bumbu masakan dan berkhasiat sebagai obat untuk berbagai macam penyakit. Kebutuhan konsumen terhadap bawang merah terus meningkat, namun ketersediaan bawang merah di Provinsi Riau belum tercukupi. Upaya yang dapat dilakukan untuk mencukupi kebutuhan bawang merah adalah dengan perluasan areal tanam bawang merah dan perbaikan teknik budidaya melalui pemupukan dan penggunaan Zat Pengatur Tumbuh (ZPT). Pemberian pupuk dapat menggunakan pupuk kalium sedangkan pemberian ZPT dapat menggunakan giberelin.

Giberelin merupakan salah satu fitohormon yang dapat mempercepat pertumbuhan bagian-bagian tanaman (Abidin 1990). Gardner et al. (1991) menyatakan bahwa giberelin mempunyai peranan penting dalam mendukung perpanjangan sel, aktivitas kambium dan sintesis DNA baru, serta pembentukan protein. Kusumo (1984), menyatakan bahwa giberelin diaplikasikan ke tanaman dengan tujuan untuk meningkatkan komponen hasil tanaman tersebut. Menurut Lakitan (1990), keberhasilan aplikasi giberelin sangat ditentukan oleh faktor internal dan eksternal, salah satu faktor eksternal yang perlu diperhatikan adalah konsentrasi. Menurut penelitian yang pernah dilakukan Pramukyana et al. (2016) menunjukkan bahwa $\mathrm{GA}_{3}$ pada konsentrasi 100 ppm dapat meningkatkan pembungaan dan berat umbi tanaman bawang merah per plot.

Giberelin pada konsentrasi yang tepat akan berdampak baik jika ketersediaan hara dalam tanah juga tercukupi. Salah satu unsur hara yang dapat mendukung pertumbuhan dan perkembangan tanaman bawang merah adalah kalium. Unsur kalium dapat diberikan melalui pemberian pupuk KCl. Sarief (1986) menyatakan bahwa kalium berperan dalam berbagai proses di dalam tanaman diantaranya pembukaan stomata, berperan dalam proses fisiologis, mempengaruhi penyerapan unsurunsur lain dan berperan dalam perkembangan akar. Menurut Munawar (2011) kalium berperan dalam mempertahankan turgor, memperkuat batang tanaman serta dapat meningkatkan ketahanan tanaman terhadap penyakit. Wibowo (2007) menyatakan bahwa rekomendasi pupuk $\mathrm{KCl}$ untuk tanaman bawang merah yaitu $150 \mathrm{~kg}-200 \mathrm{~kg}$ per hektar.

Pemberian giberelin dan pupuk $\mathrm{KCl}$ dapat meningkatkan pertumbuhan dan produksi dari tanaman bawang merah. Berdasarkan permasalahan di atas, maka penulis melakukan penelitian dengan judul "Pengaruh Pemberian Giberelin dan Pupuk Kalium terhadap Pertumbuhan dan Produksi Tanaman Bawang Merah (Allium ascalonicum L.)".

Penelitian ini bertujuan untuk mengetahui pengaruh interaksi pemberian giberelin dan dosis kalium. Mengetahui pengaruh dosis pupuk kalium yang lebih baik pada berbagai konsentrasi giberelin, konsentrasi giberelin yang lebih baik pada berbagai dosis kalium, dan mengetahui pengaruh utama pupuk kalium dan giberelin yang lebih baik untuk pertumbuhan dan produksi tanaman bawang merah.

\section{METODOLOGI PENELITIAN}

Penelitian ini telah dilaksanakan di Kebun Percobaan, Fakultas Pertanian Kampus Binawidya Universitas Riau, Pekanbaru. Penelitian dilaksanakan pada bulan Desember 2018 hingga Februari 2019. Bahan yang digunakan dalam penelitian ini adalah bibit bawang merah varietas Bima Brebes, Giberelin (merek dagang Biotech A), pupuk $\mathrm{KCl}$, Urea dan TSP, pupuk kandang, pestisida Dithane M45, dan kertas label. Alat yang digunakan untuk penelitian ini adalah cangkul, parang, sprayer, pancang, gelas ukur, timbangan, gembor, penggaris, pulpen, dan spidol. Penelitian dilakukan dalam bentuk percobaan yang disusun dalam Rancangan Petak Terbagi dengan menggunakan Rancangan Acak Lengkap (RAL), sebagai petak utama adalah $\mathrm{ZPT} \mathrm{GA}_{3}$ dan anak petak adalah pupuk $\mathrm{KCl}$.

Petak utama adalah giberelin konsentrasi $(0,100,200$ dan 300) ppm. Anak petak pupuk kalium dosis (100 dan 200) $\mathrm{kg} \mathrm{KCl} \mathrm{ha}{ }^{-1}$. Berdasarkan kedua faktor tersebut diperoleh 8 kombinasi perlakuan, masing-masing perlakuan diulang sebanyak 3 kali sehingga didapat 24 plot percobaan. Tiap plot percobaan terdiri dari 50 tanaman 10 diantaranya dijadikan tanaman sampel. Data yang diperoleh dianalisis secara statistik menggunakan sidik ragam dan dilanjutkan 
dengan uji jarak berganda Duncan pada taraf 5\%. Parameter yang diamati adalah tinggi tanaman, jumlah daun, jumlah umbi per rumpun, diameter umbi, berat segar umbi per rumpun, berat segar umbi per plot, dan berat umbi layak simpan.

\section{HASIL DAN PEMBAHASAN}

\section{Tinggi Tanaman}

Tabel 1. Tinggi Tanaman Bawang Merah Setelah Diperlakukan dengan Giberelin dan Pupuk KCl.

\begin{tabular}{cccc}
\hline Konsentrasi & \multicolumn{2}{c}{ Dosis Pupuk KCl (kg.ha-1) } & Rerata Giberelin \\
\cline { 2 - 3 } Giberelin $(\mathrm{ppm})$ & 100 & 200 & \\
\hline & $---10,20 \mathrm{a}$ \\
100 & $35,03 \mathrm{ab}$ & $37,37 \mathrm{a}$ & $36,30 \mathrm{a}$ \\
200 & $35,09 \mathrm{ab}$ & $37,60 \mathrm{a}$ & $37,32 \mathrm{a}$ \\
300 & $37,01 \mathrm{a}$ & $37,63 \mathrm{a}$ & $36,26 \mathrm{a}$ \\
\hline Rerata KCl & $35,02 \mathrm{ab}$ & $37,50 \mathrm{a}$ & \\
\hline
\end{tabular}

Angka-angka pada kolom yang sama diikuti oleh huruf kecil yang sama dan angka-angka pada baris yang sama diikuti oleh huruf kapital yang sama berbeda tidak nyata menurut uji Jarak Berganda Duncan taraf 5\%.

Data pengamatan pada Tabel 1 menunjukkan bahwa peningkatan dosis $\mathrm{KCl}$ pada konsentrasi giberelin yang sama menghasilkan tinggi tanaman bawang merah yang cenderung sama. Peningkatan konsentrasi giberelin pada dosis kalium $200 \mathrm{~kg} \cdot \mathrm{ha}^{-1}$ menghasilkan tinggi tanaman bawang merah yang relatif sama, tetapi untuk dosis kalium $100 \mathrm{~kg} \cdot \mathrm{ha}^{-1}$ pemberian konsentrasi giberelin $200 \mathrm{ppm}$ menghasilkan tanaman tertinggi dan berbeda nyata dengan pemberian giberelin pada konsentrasi 0, 100 dan 300 ppm. Pemberian $\mathrm{KCl}$ pada dosis yang tinggi tidak langsung menghambat pertumbuhan tanaman karena tanaman dapat menyerap kalium lebih banyak diatas kebutuhan normal atau disebut dengan istilah luxury compsumtion. Menurut Lakitan (1990), jika jaringan tumbuhan mengandung unsur hara tertentu dengan dosis yang lebih tinggi dari dosis yang dibutuhkan untuk pertumbuhan maksimum, maka pada kondisi ini dikatakan tumbuhan dalam kondisi konsumsi mewah.

Pemberian giberelin sebagai petak utama pada peningkatan konsentrasi hingga 300 ppm menghasilkan tinggi tanaman berbeda tidak nyata dengan pemberian pada konsentrasi lainnya. Hal ini diduga karena giberelin secara tunggal tidak langsung memacu pertumbuhan tinggi tanaman karena giberelin bukan termasuk nutrisi, giberelin akan berdampak baik apabila ketersediaan hara juga mencukupi. Wattimena (1988) menyatakan bahwa zat
Hasil sidik ragam menunjukkan bahwa interaksi giberelin dengan pupuk $\mathrm{KCl}$, dan pemberian giberelin berpengaruh tidak nyata terhadap tinggi tanaman bawang merah, sedangkan pemberian kalium sebagai anak petak berpengaruh nyata. Tinggi tanaman setelah dilakukan uji Jarak Berganda Duncan pada taraf 5\% dapat dilihat pada Tabel 1. pengatur tumbuh bukan termasuk nutrisi dan akan berdampak baik apabila unsur hara juga terpenuhi. Hasil dari penelitian Sumarni et al. (2012) menunjukkan aplikasi giberelin pada konsentrasi 100 - 200 ppm tidak meningkatkan tinggi tanaman bawang merah.

Pemberian pupuk $\mathrm{KCl}$ sebagai anak petak pada dosis $200 \mathrm{~kg} \mathrm{ha}^{-1}$ nyata meningkatkan tinggi tanaman dibandingkan dengan pemberian pupuk $\mathrm{KCl} 100 \mathrm{~kg} \cdot \mathrm{ha}^{-1}$. Pemberian pupuk KCl $200 \mathrm{~kg} \cdot \mathrm{ha}^{-1}$ mampu memenuhi kebutuhan unsur hara tanaman. Menurut Novizan (2002), pertumbuhan tanaman akan lebih optimal apabila unsur hara yang dibutuhkan tersedia dalam jumlah yang cukup dan sesuai dengan kebutuhan tanaman.

\section{Jumlah Daun}

Hasil sidik ragam menunjukkan bahwa interaksi giberelin dengan pupuk kalium dan petak utama giberelin berpengaruh tidak nyata terhadap jumlah daun tanaman bawang merah tetapi pemberian kalium sebagai anak petak berpengaruh nyata. Jumlah daun tanaman setelah dilakukan uji Jarak Berganda Duncan pada taraf 5\% dapat dilihat pada Tabel 2.

Data pengamatan jumlah daun tanaman bawang merah pada Tabel 2 menunjukkan bahwa peningkatan dosis $\mathrm{KCl}$ pada konsentrasi giberelin 100, 200 dan 300 ppm menghasilkan jumlah daun yang relatif sama, tetapi pemberian pupuk $\mathrm{KCl} 200 \mathrm{~kg} \cdot \mathrm{ha}^{-1}$ tanpa pemberian giberelin nyata meningkatkan 
jumlah daun dibandingkan dengan perlakuan pupuk $\mathrm{KCl} 100 \quad \mathrm{~kg} \cdot \mathrm{ha}^{-1}$ tanpa giberelin. Pemberian giberelin pada konsentrasi 100 dam 200 ppm dengan penambahan $\mathrm{KCl} 100 \mathrm{~kg} \cdot \mathrm{ha}^{-1}$ jumlah daun nyata lebih banyak dibandingkan dengan perlakuan $0 \mathrm{ppm}$ dan $300 \mathrm{ppm}$ pada dosis $\mathrm{KCl}$ yang sama. $\mathrm{KCl} 100 \mathrm{~kg}^{-h^{-1}}$ telah menyediakan unsur hara yang dibutuhkan tanaman sehingga dengan penambahan giberelin lebih memacu proses pembelahan sel dan diferensiasi sel yang mengarah ke pertambahan jumlah daun tanaman.

Tabel 2. Jumlah Daun Tanaman Bawang Merah Setelah Diperlakukan Dengan Giberelin dan Pupuk $\mathrm{KCl}$.

\begin{tabular}{|c|c|c|c|}
\hline \multirow{2}{*}{$\begin{array}{c}\text { Konsentrasi } \\
\text { Giberelin (ppm) }\end{array}$} & \multicolumn{2}{|c|}{ Dosis Pupuk KCl $\left(\mathrm{kg} \cdot \mathrm{ha}^{-1}\right)$} & \multirow{2}{*}{ Rerata Giberelin } \\
\hline & 100 & 200 & \\
\hline & \multicolumn{3}{|c|}{............................................... helai } \\
\hline 0 & $23,63 \mathrm{~b}$ & $26,40 \mathrm{ab}$ & $25,02 \mathrm{c}$ \\
\hline 100 & $26,37 \mathrm{a}$ & $29,13 \mathrm{a}$ & $27,75 \mathrm{ab}$ \\
\hline 200 & $28,83 \mathrm{a}$ & $28,53 \mathrm{a}$ & 28,68 a \\
\hline 300 & $25,77 \mathrm{ab}$ & $26,30 \mathrm{ab}$ & $26,03 \mathrm{bc}$ \\
\hline Rerata $\mathrm{KCl}$ & $25,90 \mathrm{~b}$ & $27,84 \mathrm{a}$ & \\
\hline
\end{tabular}

Angka-angka pada kolom yang sama diikuti oleh huruf kecil yang sama dan angka-angka pada baris yang sama diikuti oleh huruf kapital yang sama berbeda tidak nyata menurut uji Jarak Berganda Duncan taraf $5 \%$.

Pemberian giberelin sebagai petak utama pada konsentrasi $100 \mathrm{ppm}$ menghasilkan jumlah daun tanaman bawang merah yang nyata lebih banyak dibandingkan dengan pemberian giberelin 0 ppm dan $300 \mathrm{ppm}$, tetapi cenderung sama dengan pemberian $200 \mathrm{ppm}$. Pemberian giberelin pada konsentrasi yang tepat diduga dapat membantu metabolisme pembelahan sel tanaman untuk pertumbuhan jumlah daun tanaman. Giberelin pada konsentrasi rendah belum memberikan efek terhadap tanaman sementara giberelin pada konsentrasi tinggi dapat menghambat pertumbuhan dan perkembangan tanaman. Lakitan (1990) menyatakan bahwa manfaat giberelin sebagai zat pengatur tumbuh tanaman sangat ditentukan oleh berbagai faktor, salah satunya pengaturan konsentrasi.

Pemberian pupuk $\mathrm{KCl}$ sebagai anak petak pada dosis $200{\mathrm{~kg} . h a^{-1}}$ nyata meningkatkan jumlah daun tanaman bawang merah dibandingkan dengan pemberian pupuk $\mathrm{KCl} 100 \mathrm{~kg} \cdot \mathrm{ha}^{-1}$. Hal ini karena ketersediaan kalium lebih baik dalam mendukung proses metabolisme tanaman. Peran kalium dalam tanaman yaitu sebagai pengaktif beberapa enzim, pengatur air dan energi, pemindahan fotosintat, serta berperan dalam sintesis protein dan pati (Munawar, 2011).

\section{Jumlah Umbi}

Hasil sidik ragam menunjukkan bahwa interaksi giberelin dengan pupuk kalium, pemberian giberelin sebagai petak utama dan pemberian kalium sebagai anak petak berpengaruh tidak nyata terhadap jumlah umbi tanaman bawang merah. Jumlah umbi tanaman bawang merah setelah dilakukan uji Jarak Berganda Duncan pada taraf 5\% dapat dilihat pada Tabel 3.

Tabel 3. Jumlah Umbi Tanaman Bawang Merah Setelah Diperlakukan dengan Giberelin dan Pupuk $\mathrm{KCl}$.

\begin{tabular}{|c|c|c|c|}
\hline \multirow{2}{*}{$\begin{array}{l}\text { Konsentrasi Giberelin } \\
(\mathrm{ppm})\end{array}$} & \multicolumn{2}{|c|}{ Dosis Pupuk KCl $\left(\mathrm{kg} \cdot \mathrm{ha}^{-1}\right)$} & \multirow{2}{*}{ Rerata Giberelin } \\
\hline & 100 & 200 & \\
\hline \multicolumn{4}{|c|}{...buah. } \\
\hline 0 & $8,77 \mathrm{a}$ & $8,33 \mathrm{a}$ & $8,55 \mathrm{a}$ \\
\hline 100 & $8,90 \mathrm{a}$ & $8,87 \mathrm{a}$ & $8,88 \mathrm{a}$ \\
\hline 200 & $9,37 \mathrm{a}$ & $9,07 \mathrm{a}$ & $9,22 \mathrm{a}$ \\
\hline 300 & $8,27 \mathrm{a}$ & $7,50 \mathrm{a}$ & $7,88 \mathrm{a}$ \\
\hline Rerata $\mathrm{KCl}$ & $8,82 \mathrm{a}$ & $8,44 \mathrm{a}$ & \\
\hline
\end{tabular}

Angka-angka pada kolom yang sama diikuti oleh huruf kecil yang sama dan angka-angka pada baris yang sama diikuti oleh huruf kapital yang sama berbeda tidak nyata menurut uji Jarak Berganda Duncan taraf $5 \%$. 
Peningkatan dosis $\mathrm{KCl}$ pada konsentrasi giberelin yang sama menghasilkan jumlah umbi per rumpun yang berbeda tidak nyata. Peningkatan konsentrasi giberelin pada dosis $\mathrm{KCl}$ yang sama berbeda tidak nyata terhadap jumlah umbi tanaman bawang merah. Hal tersebut diduga karena jumlah umbi lebih dipengaruhi oleh sifat genetik tanaman ataupun varietas tanaman bawang merah. Jumlah umbi ditentukan oleh jumlah tunas lateral yang terdapat pada bibit umbi bawang merah. Jumlah umbi yang dihasilkan dari perlakuan diatas yaitu $8-9$ umbi. Jika dibandingkan dengan rerata jumlah umbi yang dihasilkan tanaman bawang merah varietas Bima Brebes yaitu 7-12 anaka yang artinya jumlah umbi pada perlakuan tersebut diatas telah mencapai deskripsi. Menurut Gunawan (2010) jumlah umbi lebih ditentukan oleh kemampuan umbi utama dan umbi samping dalam membentuk umbi baru. Penggunaan bibit tanaman bawang merah yang seragam dalam membentuk umbi baru tidak berbeda nyata sekalipun mendapat perlakuan yang berbeda. Tanaman bawang merah memiliki discus yang bentuknya seperti cakram, pada cakram terdapat tunas lateral yang tumbuh menjadi tanaman baru dan membentuk umbi lapis yang baru.

\section{Diameter Umbi}

Hasil sidik ragam menunjukkan bahwa interaksi giberelin dengan kalium, dan pemberian pupuk kalium sebagai anak petak berpengaruh tidak nyata terhadap diameter umbi. tanaman bawang merah tetapi pemberian giberelin sebagai petak utama berpengaruh nyata. Diameter umbi setelah dilakukan uji Jarak Berganda Duncan pada taraf 5\% dapat dilihat pada Tabel 4.

Tabel 4. Diameter Umbi Tanaman Bawang Merah Setelah Diperlakukan dengan Giberelin dan Pupuk $\mathrm{KCl}$.

\begin{tabular}{cccc}
\hline $\begin{array}{c}\text { Konsentrasi } \\
\text { Giberelin }(\mathrm{ppm})\end{array}$ & \multicolumn{2}{c}{ Dosis Pupuk KCl (kg.ha $\left.{ }^{-1}\right)$} & \multirow{2}{*}{ Rerata Giberelin } \\
\cline { 2 - 3 } 0 & 100 & 200 & $2,11 \mathrm{a}$ \\
100 & $1,97 \mathrm{ab}$ & $\ldots \ldots \ldots \ldots \ldots \ldots \ldots \ldots \ldots \ldots \ldots \ldots \ldots \ldots \ldots \ldots \ldots \ldots \ldots \ldots \ldots \ldots \ldots \ldots \ldots \ldots \ldots \ldots \ldots \ldots \ldots \ldots \ldots \ldots \ldots \ldots \ldots \ldots \ldots \ldots \ldots \ldots \ldots \ldots \ldots \ldots \ldots \ldots$ \\
200 & $2,11 \mathrm{a}$ & $2,25 \mathrm{a}$ & $2,19 \mathrm{a}$ \\
300 & $2,05 \mathrm{a}$ & $2,27 \mathrm{a}$ & $2,03 \mathrm{a}$ \\
\hline Rerata $\mathrm{KCl}$ & $1,92 \mathrm{a}$ & $2,02 \mathrm{ab}$ & $1,87 \mathrm{~b}$ \\
\hline
\end{tabular}

Angka-angka pada kolom yang sama diikuti oleh huruf kecil yang sama dan angka-angka pada baris yang sama diikuti oleh huruf kapital yang sama berbeda tidak nyata menurut uji Jarak Berganda Duncan taraf $5 \%$.

Peningkatan dosis pupuk $\mathrm{KCl}$ dengan pemberian giberelin 100, 200 dan 300 ppm menghasilkan diameter umbi tanaman yang relatif sama. Pemberian pupuk $\mathrm{KCl} 200 \mathrm{~kg} \cdot \mathrm{ha}^{-1}$ tanpa pemberian giberelin nyata meningkatkan diameter umbi dibandingkan dengan perlakuan pupuk KCl $100 \mathrm{~kg} \cdot \mathrm{ha}^{-1}$ tanpa giberelin. Hal ini diduga karena pemberian $\mathrm{KCl} 200 \mathrm{~kg} \cdot \mathrm{ha}^{-1}$ telah maksimal memacu proses fisiologis yang terjadi dalam pembesaran umbi tanaman bawang merah sehingga tidak terlalu dibutuhkan penambahan giberelin.

Pemberian pupuk $\mathrm{KCl}$ sebagai anak petak pada dosis $200 \mathrm{~kg} \cdot \mathrm{ha}^{-1}$ menghasilkan diameter umbi yang cenderung sama dengan perlakuan pupuk $\mathrm{KCl} 100 \mathrm{~kg}^{-h^{-1}}{ }^{-1}$ Kalium diduga dapat diserap oleh tanaman meskipun melebihi jumlah kebutuhan tanaman itu sendiri. Menurut Novizan (2002) kalium diserap oleh tanaman dalam jumlah yang cukup besar atau bahkan kadang melebihi jumlah kebutuhan terutama pada tanaman umbi-umbian salah satunya tanaman bawang merah.

Pemberian giberelin sebagai petak utama pada konsentrasi 100 dan 200 ppm menghasilkan diameter umbi tanaman yang relatif sama dengan perlakuan tanpa giberelin, tetapi berbeda nyata dengan perlakuan giberelin $300 \mathrm{ppm}$. Hal ini memperlihatkan bahwa diameter umbi tidak terpengaruh oleh pemberian giberelin. Respon tanaman terhadap giberelin diduga berbeda-beda antara jenis atau varietas tanaman itu sendiri. Menurut Lakitan (1990) keberhasilan aplikasi giberelin sebagai ZPT juga ditentukan oleh jenis tanaman, varietas, dan kondisi tanaman tersebut.

\section{Berat Segar Umbi per Rumpun dan Berat Segar Umbi per Plot}

Hasil sidik ragam menunjukkan bahwa interaksi giberelin dengan pupuk kalium berpengaruh nyata terhadap berat segar umbi per rumpun bawang merah sedangkan 
pemberian giberelin sebagai petak utama dan pemberian kaliumsebagai anak petak berpengaruh tidak nyata (Tabel 5). Interaksi giberelin dengan pupuk kalium, dan kalium sebagai anak petak berpengaruh tidak nyata terhadap berat segar per plot bawang merah tetapi perlakuan petak utama giberelin berpengaruh nyata. Berat segar umbi per rumpun dan per plot setelah dilakukan uji Jarak Berganda Duncan pada taraf 5\% dapat dilihat pada Tabel 5 dan Tabel 6 .

Tabel 5. Berat Segar Umbi per Rumpun Tanaman Bawang Merah Setelah Diperlakukan dengan Giberelin dan Pupuk KCl.

\begin{tabular}{|c|c|c|c|}
\hline \multirow{2}{*}{$\begin{array}{l}\text { Konsentrasi Giberelin } \\
(\mathrm{ppm})\end{array}$} & \multicolumn{2}{|c|}{ Dosis Pupuk KCl (kg.ha $\left.^{-1}\right)$} & \multirow{2}{*}{ Rerata Giberelin } \\
\hline & 100 & 200 & \\
\hline 0 & $50.70 \mathrm{ab}$ & ......g....... & $\cdots \cdots$ \\
\hline 100 & $50,96 \mathrm{ab}$ & $53,47 \mathrm{a}$ & $52,22 \mathrm{a}$ \\
\hline 200 & $58,97 \mathrm{a}$ & $51,95 \mathrm{ab}$ & 55,46 a \\
\hline 300 & $44,23 \mathrm{ab}$ & $38,81 \mathrm{ab}$ & $41,52 \mathrm{~b}$ \\
\hline
\end{tabular}

Angka-angka pada kolom yang sama diikuti oleh huruf kecil yang sama dan angka-angka pada baris yang sama diikuti oleh huruf kapital yang sama berbeda tidak nyata menurut uji Jarak Berganda Duncan taraf 5\%.

Tabel 6. Berat Segar Umbi per Plot Tanaman Bawang Merah Setelah Diperlakukan dengan Giberelin dan Pupuk KCl

\begin{tabular}{|c|c|c|c|}
\hline \multirow{2}{*}{$\begin{array}{l}\text { Konsentrasi Giberelin } \\
\text { (ppm) }\end{array}$} & \multicolumn{2}{|c|}{ Dosis Pupuk KCl $\left(\mathrm{kg} \cdot \mathrm{ha}^{-1}\right)$} & \multirow{2}{*}{ Rerata Giberelin } \\
\hline & 100 & 200 & \\
\hline & & $\ldots \ldots \ldots . \mathrm{g} \ldots \ldots$. & $\ldots .$. \\
\hline 0 & $1906,67 \mathrm{ab}$ & 2028,92 a & $1968,30 \mathrm{ab}$ \\
\hline 100 & $2050,20 \mathrm{ab}$ & $2113,33 \mathrm{a}$ & $2081,76 a b$ \\
\hline 200 & 2703,33 a & $2030,50 \mathrm{a}$ & $2366,91 \mathrm{a}$ \\
\hline 300 & $1790,40 \mathrm{ab}$ & $1376,67 \mathrm{ab}$ & $1583,33 \mathrm{~b}$ \\
\hline Rerata $\mathrm{KCl}$ & $2112,65 \mathrm{a}$ & $1887,35 \mathrm{a}$ & \\
\hline
\end{tabular}

Angka-angka pada kolom yang sama diikuti oleh huruf kecil yang sama dan angka-angka pada baris yang sama diikuti oleh huruf kapital yang sama berbeda tidak nyata menurut uji Jarak Berganda Duncan taraf 5\%.

Data pengamatan berat segar umbi per rumpun pada Tabel 5 menunjukkan bahwa peningkatan dosis $\mathrm{KCl}$ pada konsentrasi giberelin yang sama menghasilkan berat segar umbi yang relatif sama. Peningkatan konsentrasi giberelin 0 ppm sampai 200 ppm dengan penambahan 100 dan $200 \mathrm{~kg} \cdot \mathrm{ha}^{-1} \mathrm{KCl}$ menghasilkan berat segar umbi tanaman bawang merah yang berbeda tidak nyata, namun jika ditingkatkan menjadi 300 ppm justru menghasilkan berat segar yang lebih rendah.

Data pada Tabel 6 menunjukkan bahwa peningkatan dosis $\mathrm{KCl}$ pada konsentrasi giberelin yang sama menghasilkan berat segar umbi yang relatif sama. Pemberian giberelin pada konsentrasi 200 ppm dengan penambahan $\mathrm{KCl} 100 \mathrm{~kg} \cdot \mathrm{ha}^{-1}$ nyata meningkatkan berat segar umbi per plot. Hal ini diduga karena dosis $\mathrm{KCl} 100 \mathrm{~kg} \cdot \mathrm{ha}^{-1}$ telah mampu mencukupi kebutuhan hara tanaman sehingga dengan penambahan giberelin $200 \mathrm{ppm}$ mampu mendukung proses fotosintesis yang mengarah ke pengisian fotosintat ke dalam umbi tanaman. Sama halnya pada Tabel 5 pemberian pupuk KCl $100 \mathrm{~kg} \cdot \mathrm{ha}^{-1}$ dengan penambahan giberelin $200 \mathrm{ppm}$ lebih baik dalam meningkatkan berat segar umbi per rumpun. Namun jika KCl 200 kg.ha ${ }^{-1}$ sepertinya tidak terlalu dibutuhkan penambahan giberelin.

Berat segar umbi secara tidak langsung dapat dipengaruhi oleh diameter umbi. Diameter umbi yang lebih besar seharusnya menambah berat segar umbi per rumpun dan per plot. Peningkatan berat segar umbi berbanding lurus dengan data pada Tabel 4 yaitu diameter umbi tanaman. Menurut Rismunandar (1990) bobot umbi segar juga dipengaruhi oleh diameter umbi.

Pemberian pupuk $\mathrm{KCl}$ sebagai anak petak pada dosis $100 \mathrm{~kg} \cdot \mathrm{ha}^{-1}$ menghasilkan berat segar yang berbeda tidak nyata dengan perlakuan pupuk KCl $200 \mathrm{~kg} \cdot \mathrm{ha}^{-1}$. Perlakuan pupuk $\mathrm{KCl}$ menunjukkan bahwa peningkatan dosis yang diberi menghasilkan berat segar umbi yang cenderung lebih kecil. Hal ini diduga karena ketersediaan unsur hara $\mathrm{K}$ yang berlebihan. Jika jaringan tumbuhan 
Pengaruh Pemberian Giberelin dan Pupuk Kalium terhadap Pertumbuhan dan Produksi Tanaman Bawang Merah (Allium ascalonicum L.)

mengandung unsur hara tertentu dengan konsentrasi yang lebih tinggi dari konsentrasi yang dibutuhkan untuk pertumbuhan maksimum, maka pada kondisi ini dikatakan tumbuhan dalam kondisi konsumsi mewah (Lakitan, 1990). Hasil penelitian Napitupulu dan Winarno (2010), menunjukkan bahwa penambahan pupuk $\mathrm{KCl} 100 \mathrm{~kg} \cdot \mathrm{ha}^{-1}$ nyata meningkatkan hasil bawang merah.

Petak utama giberelin konsentrasi 0 sampai 200 ppm menghasilkan berat segar umbi yang berbeda tidak nyata, namun pemberian giberelin 200 ppm menghasilkan berat segar yang lebih baik dibandingkan dengan pemberian giberelin 0 dan $100 \mathrm{ppm}$. Peningkatan konsentrasi giberelin hingga 300 ppm justru menghasilkan berat segar yang lebih rendah. Giberelin pada konsentrasi yang tepat diduga dapat memacu pembesaran sel dan mampu mengatur penyerapan air pada umbi sehingga terjadi pembesaran umbi lapis.
Latarang dan Syakur (2006) menyatakan bahwa berat umbi bawang merah sangat ditentukan oleh kadar air yang terdapat pada sel penyusun lapisan umbi. Menurut Gardner et al. (1991) penambahan giberelin pada saat tanaman mengalami fase vegetatif mampu meningkatkan berat brangkasan segar. Banyaknya daun akan meningkatkan proses fotosintesis maka menghasilkan banyak fotosintat yang kemudian ditranslokasikan ke organ tanaman penyimpanan seperti umbi.

\section{Berat Umbi Layak Simpan}

Hasil sidik ragam menunjukkan bahwa interaksi giberelin dengan pupuk $\mathrm{KCl}$, pemberian pupuk kaliums sebagai anak petak berpengaruh tidak nyata terhadap berat umbi layak simpan bawang merah, tetapi pemberian giberelin sebagai petak utama berpengaruh nyata. Berat umbi layak simpan setelah dilakukan uji Jarak Berganda Duncan pada taraf 5\% dapat dilihat pada Tabel 7 .

Tabel 7. Berat Umbi Layak Simpan Tanaman Bawang Merah Setelah Diperlakukan dengan Giberelin dan Pupuk KCl.

\begin{tabular}{|c|c|c|c|}
\hline \multirow{2}{*}{$\begin{array}{c}\text { Konsentrasi Giberelin } \\
(\mathrm{ppm})\end{array}$} & \multicolumn{2}{|c|}{ Dosis Pupuk KCl $\left(\mathrm{kg} \cdot \mathrm{ha}^{-1}\right)$} & \multirow{2}{*}{ Rerata Giberelin } \\
\hline & 100 & 200 & \\
\hline & \multicolumn{3}{|c|}{ 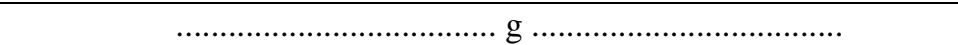 } \\
\hline 0 & $1603,33 \mathrm{ab}$ & $1843,33 \mathrm{a}$ & $1723,33 \mathrm{a}$ \\
\hline 100 & $1793,33 \mathrm{ab}$ & $1860,70 \mathrm{a}$ & $1827,01 \mathrm{a}$ \\
\hline 200 & $2116,67 \mathrm{a}$ & $1970,91 \mathrm{a}$ & 2043,79 a \\
\hline 300 & $1406,67 \mathrm{ab}$ & $1080,42 \mathrm{ab}$ & $1243,54 \mathrm{~b}$ \\
\hline Rerata $\mathrm{KCl}$ & $1730,00 \mathrm{a}$ & $1688,84 \mathrm{a}$ & \\
\hline
\end{tabular}

Angka-angka pada kolom yang sama diikuti oleh huruf kecil yang sama dan angka-angka pada baris yang sama diikuti oleh huruf kapital yang sama berbeda tidak nyata menurut uji Jarak Berganda Duncan taraf $5 \%$.

Peningkatan dosis pupuk $\mathrm{KCl}$ pada konsentrasi giberelin yang sama menghasilkan berat umbi layak simpan tanaman bawang merah yang berbeda tidak nyata. Peningkatan konsentrasi giberelin sampai 200 ppm dengan penambahan $\mathrm{KCl} 200 \mathrm{~kg} \cdot \mathrm{ha}^{-1}$ menghasilkan berat umbi layak simpan tanaman bawang merah yang cenderung sama. Pemberian konsentrasi giberelin 200 ppm dengan penambahan $\mathrm{KCl} 100 \quad \mathrm{~kg} \cdot \mathrm{ha}^{-1}$ nyata meningkatkan berat umbi layak simpan dibandingkan pemberian giberelin konsentrasi 0 dan 100 ppm dengan penambahan pupuk $\mathrm{KCl} 100 \quad \mathrm{~kg}^{-h^{-1}}$, pemberian konsentrasi giberelin sampai $300 \mathrm{ppm}$ pada berbagai dosis $\mathrm{KCl}$ justru menghasilkan berat umbi layak simpan cenderung rendah. Demikian juga dengan berat segar umbi per rumpun (Tabel 5) dan berat segar umbi per plot (Tabel 6) mengalami peningkatan pada saat diberikan giberelin $200 \mathrm{ppm}$ dengan $\mathrm{KCl} 100 \mathrm{~kg} \cdot \mathrm{ha}^{-1}$. Diduga kalium pada $100 \mathrm{~kg} \cdot \mathrm{ha}^{-1}$ mampu mencukupi kebutuhan hara tanaman sehingga dengan penambahan giberelin $200 \mathrm{ppm}$ mampu mendukung peningkatan berat umbi layak simpan. Hal ini juga sesuai dengan pernyataan Wattimena (1988) yang menyatakan bahwa ZPT akan memberikan pengaruh terhadap fisiologis tanaman apabila ketersediaan hara di dalam tanaman juga cukup, karena ZPT tidak termasuk unsur hara ataupun nutrisi. Produksi tanaman biasanya lebih akurat dinyatakan dengan ukuran berat kering daripada dengan berat basah, karena berat basah sangat dipengaruhi oleh kondisi kelembaban (Sitompul dan Guritno, 1995). Apabila berat kering suatu tanaman besar, maka hasil proses metabolismenya sebesar berat kering tanaman tersebut. Berat kering dapat diartikan sebagai berapa besar tanaman 
tersebut melakukan proses fisiologis yang dicerminkan dalam bentuk berat kering (Salisbury dan Ross, 1995).

Petak utama giberelin 0 ppm sampai 200 ppm menghasilkan berat umbi layak simpan yang berbeda tidak nyata, namun pada pemberian giberelin $200 \mathrm{ppm}$ berat umbi layak simpan meningkat hingga 14,6 \% dibandingkan tanpa pemberian giberelin. Peningkatan konsentrasi giberelin hingga 300 ppm justru menghasilkan berat umbi layak simpan yang lebih rendah. Hal ini diduga karena giberelin berperan dalam proses fotosintesis tanaman sehingga memacu tanaman bawang merah untuk melakukan pengisian umbi dan penyimpanan fotosintat namun pada konsentrasi yang lebih tinggi dapat menghambat proses perkembangan umbi tanaman bawang merah. Menurut Lakitan (1990), berat kering tanaman mencerminkan akumulasi senyawa organik yang berhasil disintesis tanaman dari senyawa anorganik. Unsur hara yang telah diserap akar, baik yang digunakan dalam sintesis senyawa organik maupun yang tetap dalam bentuk ionik dalam jaringan tanaman, berkontribusi terhadap pertambahan berat kering tanaman.

Pemberian pupuk $\mathrm{KCl}$ sebagai anak petak pada dosis $200 \mathrm{~kg} \cdot \mathrm{ha}^{-1}$ menghasilkan berat umbi layak simpan yang lebih rendah walaupun berbeda tidak nyata dibandingkan dengan perlakuan pupuk $\mathrm{KCl} 100 \mathrm{~kg} \cdot \mathrm{ha}^{-1}$. Demikian juga berat segar umbi per plot pada Tabel 6 yang menunjukkan bahwa pemberian $\mathrm{KCl} 100 \mathrm{~kg}$.ha menghasilkan berat segar yang lebih baik dibandingkan dengan $\mathrm{KCl} 200$ kg.ha ${ }^{-1}$. Diduga kalium yang diberikan dengan dosis yang tinggi tidak langsung merusak produksi tanaman, karena kalium dapat diserap oleh tanaman melebihi jumlah kebutuhan tanaman itu sendiri. Menurut Novizan (2002) kalium dapat diserap tanaman dalam jumlah yang lebih banyak melebihi batas kebutuhan tanaman itu sendiri, dan biasanya terjadi pada tanaman umbi-umbian.

\section{KESIMPULAN DAN SARAN}

\section{Kesimpulan}

Berdasarkan penelitian yang telah dilaksanakan disimpulkan bahwa :

1. Terdapat interaksi pemberian giberelin dengan $\mathrm{KCl}$ pada parameter berat segar umbi tanaman bawang merah.
2. Pemberian $\mathrm{KCl} 100 \mathrm{~kg} \cdot \mathrm{ha}^{-1}$ dan giberelin $200 \mathrm{ppm}$ menunjukkan pertumbuhan yang lebih baik pada parameter jumlah umbi, berat segar umbi per rumpun, berat segar umbi per plot dan berat umbi layak simpan. Pemberian $\mathrm{KCl} 200 \mathrm{~kg} \cdot \mathrm{ha}^{-1}$ dan giberelin 100 ppm menunjukkan pertumbuhan yang lebih baik pada parameter jumlah daun dan diameter umbi.

3. Pemberian giberelin $200 \mathrm{ppm}$ menunjukkan hasil yang lebih baik pada parameter berat segar umbi per rumpun, berat segar umbi per plot dan berat umbi layak simpan tanaman bawang merah. Pemberian $\mathrm{KCl}$ $200 \mathrm{~kg} \cdot \mathrm{ha}^{-1}$ menunjukkan hasil yang lebih baik pada parameter pertumbuhan tinggi tanaman dan jumlah daun.

\section{Saran}

Dari hasil penelitian yang telah dilaksanakan disarankan memberikan giberelin 200 ppm dan $\mathrm{KCl} 100 \quad$ kg.ha ${ }^{-1}$ untuk mendapatkan pertumbuhan dan produksi tanaman bawang merah yang baik.

\section{DAFTAR PUSTAKA}

Abidin, Z. 1990. Dasar-dasar Pengetahuan Tentang Zat Pengatur Tumbuhan. Angkasa, Bandung.

Dwijoseputro, D. 1990. Pengantar Fiologi Tumbuhan. PT. Gramedia, Jakarta.

Gardner, F. P., R. B. Pearce, dan R. L. Mitchell. 1991. Fisiologi Tanaman Budidaya. Universitas Indonesia Press, Jakarta.

Gunawan, D. 2010. Budidaya Bawang Merah. Agritek, Jakarta.

Hasibuan, B. E. 2009. Pupuk dan Pemupukan. USU-Press, Medan.

Kusumo, S. 1984. Zat Pengatur Tumbuh Tanaman. Yasaguna, Jakarta.

Lakitan, B. 1990. Fisiologi Pertumbuhan dan Perkembangan Tanaman. Raja Grafindo Persada, Jakarta.

Latarang, B dan A. Syakur. 2006. Pertumbuhan dan Hasil Bawang Merah (Allium ascalonicum L.) pada Berbagai Dosis Pupuk Kandang. Jurnal Agroland, 13(3) : 265-269.

Munawar, A. 2011. Kesuburan Tanah dan Nutrisi Tanaman. IPB Press, Bogor.

Napitupulu, D dan L. Winarto. 2010. Pengaruh Pemberian Pupuk $\mathrm{N}$ dan $\mathrm{K}$ terhadap Pertumbuhan dan Produksi Bawang 
Merah. Jurnal Hortikultura, 20(1): 2735.

Novizan. 2002. Petunjuk Pemupukan yang Efektif. Agromedia Pustaka, Jakarta.

Poerwowidodo. 1992. Telaah Kesuburan Tanah. Angkasa, Bandung.

Pramukyana, L., N. Kendarini dan Respatijarti. 2016. Respon Pemberian Konsentrasi $\mathrm{GA}_{3}$ terhadap Pembungaan Dua Varietas Bawang Merah (Allium ascalonicum L.) Jurnal Produksi Tanaman, 6(7): 14331441.

Rismunandar. 1990. Hormon Tanaman dan Ternak. Penebar Swadaya, Jakarta.

Rukmana, N. 1994. Budidaya dan Pasca Panen Bawang Merah. Penebar Swadaya, Jakarta.

Salisburry, F dan C. W. Ross. 1995. Fisiologi Tumbuhan. Jilid 3. Diterjemahkan oleh Lukman dan Sumaryono. Institut Teknologi Bandung, Bandung.

Sarief, S. 1986. Kesuburan dan Pemupukan Tanah Pertanian. Pustaka Buana, Bandung.

Sitompul, S. M dan B. Guritno. 1995. Analisa Pertumbuhan Tanaman. Gadjah Mada University Press, Yogyakarta.

Sumarni, N., Suwandi, N. Gunaeni dan S. Putrasamedja. 2012. Pengaruh Varietas dan Cara Aplikasi $\mathrm{GA}_{3}$ terhadap Pembungaan dan Biji Hasil Bawang Merah di Dataran Tinggi Sulawesi Selatan. Jurnal Hortikultura. 23(2): 153163.

Wattimena, G. A. 1988. Zat Pengatur Tumbuh Tanaman. Laboratorium Kultur Jaringan Tanaman PAU Bioteknologi IPB, Bogor.

Wibowo, S. 2007. Budidaya Bawang Merah. Penebar Swadaya, Jakarta. 
